\title{
Axial Length of Myopia: A Review of Current Research
}

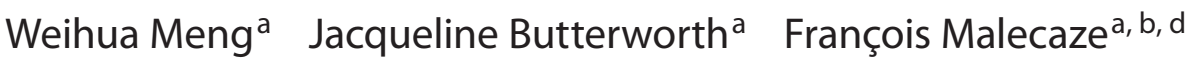 \\ Patrick Calvas ${ }^{a, c, d}$ \\ aPhysiopathology Centre, INSERM U563, and Departments of ${ }^{b}$ Ophthalmology and ${ }^{c}$ Medical Genetics, \\ Purpan Hospital, Toulouse, and ${ }^{\mathrm{d}}$ University Paul Sabatier, Toulouse, France
}

\section{Key Words}

Axial length $\cdot$ Myopia - Genetics - Refractive error .

Endophenotype

\begin{abstract}
Myopia, or nearsightedness, is a worldwide common type of refractive error. It is a non-life-threatening disorder with huge social and economic consequences due to its increasing prevalence. Axial length $(A L)$ is the primary determinant of non-syndromic myopia. It is a parameter representing the combination of anterior chamber depth, lens thickness and vitreous chamber depth of the eye. AL can also be treated as an endophenotype of myopia and may provide extra advantages in the investigation of its genetic basis. The study of AL will not only identify the determinants of eye elongation, but also provide aetiological evidence for myopia. The purpose of this review is to outline the current state of AL research. Epidemiological evidence, genetic determinants, the relationship with other eye components and relative animal models of AL are summarised.
\end{abstract}

Copyright $\odot 2010$ S. Karger AG, Base

\section{Introduction}

Myopia is a major threat for vision health across the world. It is responsible for around $75 \%$ of the refractiveerror-related complications, with serious social and eco- nomical consequences $[1,2]$. Patients with severe forms of myopia or high myopia are more susceptible to other ocular abnormalities such as lacquer cracks, retinal detachment, chorioretinal atrophy and glaucoma [3]. In Western Europe, the estimated prevalence of myopia is over 25\% [3]. Similar results have been reported in some regions such as the Middle East and South America. Table 1 summarises myopia prevalences of middle-aged groups in different areas [3-12]. Those studies revealed a relatively higher morbidity of myopia in some East Asian countries. The difference was found to be greater if preschool and school age children were evaluated (table 2) [13-24]. Studies on schoolchildren in Hong Kong and medical students in Singapore even revealed extremely high prevalences of $82 \%$ and $90 \%[25,26]$. According to a recent report from the World Health Organisation, the number of people who have visual impairment caused by myopia and other ocular disorders reached over 161 million in 2002 whereas some researchers worried that this figure was greatly underestimated [27,28].

Myopia can be classified using different criteria [29]. For example, physiological myopia and pathological myopia are differentiated by the presence of degenerative changes and the value of the refractive error (normally in diopters). Based on the age of onset, myopia can also be divided into 3 groups: youth-onset myopia (less than 20 years old), early adult-onset myopia (aged between 20 and 40) and late adult-onset myopia (over 40 years old). Other classifications include: axial myopia and non-axial my-

\section{KARGER}

Fax +4161306 1234 E-Mail karger@karger.ch www.karger.com
(C) 2010 S. Karger AG, Basel 0030-3755/11/2253-0127\$38.00/0

Accessible online at: www.karger.com/oph
Prof. Patrick Calvas

Physiopathology Centre, Purpan Hospital, INSERM U563

FR-31024 Toulouse (France)

Tel. +33 561779 079, Fax +33 561779 073, E-Mail calvas.p@ chu-toulouse.fr 
Table 1. Prevalence of myopia and high myopia in middle-aged populations

\begin{tabular}{|c|c|c|c|c|c|c|}
\hline \multirow{2}{*}{$\begin{array}{l}\text { Country or } \\
\text { region }\end{array}$} & \multirow{2}{*}{$\begin{array}{l}\text { Sample } \\
\text { number }\end{array}$} & \multirow{2}{*}{$\begin{array}{l}\text { Age distribution, } \\
\text { years }\end{array}$} & \multicolumn{2}{|c|}{ Definition of } & \multicolumn{2}{|c|}{ Prevalence of } \\
\hline & & & myopia, dpt & high myopia, dpt & myopia, \% & high myopia, \% \\
\hline Japan [4] & 3,021 & $58.4 \pm 11.8$ & $<-0.5$ & $<-5$ & 41.8 & 8.2 \\
\hline $\operatorname{Iran}[5]$ & 1,367 & $63.7 \pm 7.1$ & $<-0.5$ & & 27.2 & \\
\hline Bangladesh [6] & 11,624 & $44 \pm 12.6$ & $<-0.5$ & $<-5$ & 22.1 & 1.8 \\
\hline China, north [7] & 6,491 & $>30$ & $<-0.5$ & $<-5$ & 26.7 & 1.8 \\
\hline China, south [8] & 1,269 & $>50$ & $<-0.5$ & $<-5$ & 32.3 & 5 \\
\hline India [9] & 3,642 & $>40$ & $<-0.5$ & $<-5$ & 34.6 & 4.5 \\
\hline Singapore [10] & 1,113 & $>40$ & $<-0.5$ & $<-5$ & 38.7 & 9.1 \\
\hline Europe, west [3] & 6,543 & $>40$ & $<-1$ & $<-5$ & 26.6 & 4.6 \\
\hline USA [3] & 14,414 & $>40$ & $<-1$ & $<-5$ & 25.4 & 4.5 \\
\hline Australia [3] & 8,324 & $>40$ & $<-1$ & $<-5$ & 16.4 & 2.8 \\
\hline Norway [11] & 1,889 & $40-45$ & $<-0.5$ & & 30.3 & \\
\hline Spain [12] & 417 & $40-79$ & $<-0.5$ & & 25.4 & \\
\hline
\end{tabular}

Age distribution is preferred to be presented as means \pm standard deviation. If the references did not provide such information, then other forms of age range are shown.

opia; low myopia ( 0 to $-3 \mathrm{dpt})$, moderate myopia ( -3 to -6 dpt) and high myopia (<-6 dpt); syndromic myopia and non-syndromic myopia. To some extent, a graded classification is artificial. In the genetic domain, non-syndromic myopia can be separated into 2 categories: myopia following complex traits, which is determined by both genetic and environmental factors; myopia showing a mendelian pattern of inheritance (autosomal dominant, autosomal recessive and so on), which is normally found by family studies and mainly caused by genetic mutations.

\section{Axial Length}

There are 4 ocular structures contributing to the refractive status of a given human eye, including the cornea, aqueous humour, lens and the vitreous humour. Myopia and other refractive-error disorders are consequences of uncoordinated contributions of ocular components to overall eye structures. In other words, the cornea and lens fail to compensate for axial length (AL) elongation (myopia) or shortening (hyperopia). Thus, parameters closely linked to measurements of these parts such as corneal curvature, anterior chamber depth (ACD), lens thickness, vitreous chamber depth and AL are widely evaluated in the study of eye diseases [30]. Among these components, AL received most attention since it is a main parameter for both myopia and hypermyopia [30].
As early as the mid last century, researchers found that AL showed a bimodal distribution in an adult myopic population [31]. When grouping samples in 2 categories, a first peak appears around the AL of $24 \mathrm{~mm}$ for low myopia $(-6 \mathrm{dpt}<$ refractive error $<0 \mathrm{dpt})$ while the second peak appears roughly at the AL of $30 \mathrm{~mm}$ for high myopia (refractive error $<-6 \mathrm{dpt}$ ). This indicates that the physiopathological mechanisms of different severities of myopia may differ and partly explains why it is necessary to separate myopia cases according to the severity to explore its genetic basis. Meanwhile, the distribution of AL is reported to be positively skewed in the general population, and it is under a normal distribution in some selected cohorts [32,33]. Table 3 shows a summary of AL and its corresponding refractive error in multiple populations from different countries [33-39]. Nowadays, ophthalmologists use ultrasound velocity reading machinery and optical partial coherence interferometry to determine the AL of their patients to clarify the severity of myopia. Most agree that AL is the largest determinant of refractive error [40]. A great number of reports have shown a negative relationship between AL and myopia. In other words, the longer the AL, the severer the myopia [41, 42]. Olsen et al. [35] found that when considering the contribution of AL, lens power and corneal power together, using multiple linear regression analyses, it can explain up to $96 \%$ of the variation of refraction in populations. Age-related $\mathrm{AL}$ differences were discovered in some investigations. Older people were likely to have shorter AL than younger par- 
Table 2. Prevalence of myopia in preschool and school age children

\begin{tabular}{|c|c|c|c|c|}
\hline $\begin{array}{l}\text { Country or } \\
\text { region }\end{array}$ & $\begin{array}{l}\text { Sample } \\
\text { number }\end{array}$ & $\begin{array}{l}\text { Age } \\
\text { distribution }\end{array}$ & $\begin{array}{l}\text { Defini- } \\
\text { tion of } \\
\text { myopia } \\
\text { dpt }\end{array}$ & $\begin{array}{l}\text { Prevalence } \\
\text { of myopia } \\
\%\end{array}$ \\
\hline Singapore [13] & 3,009 & $6-72$ months & $<-0.5$ & 11.0 \\
\hline \multicolumn{5}{|l|}{ USA } \\
\hline $\begin{array}{l}\text { Urban and } \\
\text { white [14] }\end{array}$ & 1,030 & 6-71 months & $<-1$ & 0.7 \\
\hline African [15] & 2,994 & $6-72$ months & $<-1$ & 6.6 \\
\hline Hispanic [15] & 3,030 & & & 3.7 \\
\hline \multicolumn{5}{|l|}{ Australia [16] } \\
\hline Urban & 322 & 11-14 years & $<-0.5$ & 17.8 \\
\hline Rural & 270 & & & 6.9 \\
\hline China [17] & 1,892 & $14.7 \pm 0.8$ years & $<-0.5$ & 62.3 \\
\hline Iran [18] & 815 & 6 years & $<-0.5$ & 1.7 \\
\hline UK [19] & 7,600 & 7 years & $<-1$ & 1.1 \\
\hline \multirow[t]{3}{*}{ Singapore [20] } & 631 & 7 years & $<-0.5$ & 29.0 \\
\hline & 470 & 8 years & & 34.7 \\
\hline & 352 & 9 years & & 53.1 \\
\hline \multicolumn{5}{|l|}{ Poland [21] } \\
\hline Urban & 1,200 & $11.9 \pm 1.4$ years & $<-0.5$ & 13.7 \\
\hline Rural & 1,006 & & & 7.5 \\
\hline \multicolumn{5}{|l|}{ Indian [22] } \\
\hline Urban & 1,789 & $7-15$ years & $<-0.5$ & 51.4 \\
\hline Rural & 1,525 & & & 16.7 \\
\hline Sweden [23] & 143 & $4-15$ years & $<-0.5$ & 6.0 \\
\hline Malaysia [24] & 705 & $6-12$ years & $<-0.5$ & 5.4 \\
\hline
\end{tabular}

Age distribution is preferred to be presented as means \pm standard deviation. If the references did not provide such information, then other forms of age range are shown. The highest 3 are italicised.

ticipants [38]. Warrier et al. [34] suggested that these differences were related to cohort effects. For example, near work was more intensive in the younger age group, which is a factor increasing AL probably due to a defocus-induced disturbance of emmetropisation [43]. However, the Los Angeles Latino Eye Study did not reveal an age-related AL difference based on a population of 5,588 participants over a period of 40 years [44]. Meanwhile, it is well agreed that women tend to have a shorter AL [34, 35], partly explained by stature [45]. AL has some predicted values for the onset of myopia but only within the 2-4 years preceding onset [46]. It reaches its fastest rate of change during the year before the onset of myopia and then axial elongation follows relatively slowly, with more stable rates of change after onset [46].

Axial Length of Myopia

\section{AL and Ocular Biometric Components}

The visual system is not well developed until 3 years of age. In general, AL increases rapidly in the early stage of life, then slowly increases until adulthood, then decreases in old age. Data from Biino et al. [33] showed a quadratic relationship between AL and age. A cohort study reported that the average axial length for full-term infants increases from 16.8 to $23.6 \mathrm{~mm}$ when they become adults [47]. This increase in AL would cause a serious shift to myopia, which was however offset by corresponding changes in other parts of the eye structure. For example, the lens will reduce its refractive power when $\mathrm{AL}$ increases [48]. A $1-\mathrm{mm}$ elongation of AL without other compensation is equivalent to a myopia shift of -2 or $-2.5 \mathrm{dpt}$. Evidence shows that each component of the visual system has close interaction with the other components during the maturation process. Lambert [49] deduced from animal experiments that if the lens were removed from human eyes at an early stage (within the first 2 months), a retardation of eye growth would occur. Human data also support the contention that the AL of eyes after cataract surgery is shorter than in age-matched controls [50,51], although some authors have observed opposite effects [52]. A decrease in lens power is correlated with the elongation of AL but knowledge on whether this is an active or a passive emmetropisation process is rather limited to make a decisive conclusion [53]. AL was also reported to be significantly negatively correlated with corneal power and documented to have a positive correlation with ACD and a negative correlation with lens thickness [35, 54-56]. Osuobeni [55] suggested that the ratio between AL and corneal radius may be a better indicator of myopia. AL undergoes diurnal fluctuation of around 15-40 $\mu \mathrm{m}$, with a mean period of approximately $21 \mathrm{~h}$ [57]. The maximum AL appears at midday. It is reasonable to hypothesise that this phenomenon is caused by the daily change of intraocular pressure (IOP) since IOP follows diurnal fluctuation as well [58]. However, this assumption is under debate $[58,59]$. Read et al. [59] found the association between the change in AL and the change in IOP while no evidence was found by Wilson et al. [58] that IOP fluctuation appears to cause diurnal AL fluctuation.

\section{AL and Genetic Determinants}

Myopia can be treated as a mendelian trait, caused by a single gene, or a complex trait, affected by multiple genetic factors and environmental factors depending on the

Ophthalmologica 2011;225:127-134 
Table 3. AL information and its corresponding refractive error in middle-aged populations

\begin{tabular}{lllclll}
\hline Country or region & $\begin{array}{l}\text { Supplemental } \\
\text { information }\end{array}$ & $\begin{array}{l}\text { Age distribution } \\
\text { years }\end{array}$ & Study type & $\begin{array}{l}\text { Sample } \\
\text { number }\end{array}$ & $\begin{array}{l}\text { AL } \\
\text { mm }\end{array}$ & $\begin{array}{c}\text { Corresponding } \\
\text { refractive error } \\
\text { dpt }\end{array}$ \\
\hline Sardinia, Italy [33] & $\begin{array}{l}\text { right eye } \\
\text { left eye }\end{array}$ & $41 \pm 19$ & family & 741 & $\begin{array}{l}23.57 \pm 1.15 \\
23.51 \pm 1.06\end{array}$ & $-0.27 \pm 2.11$ \\
& male & $56.2 \pm 11.5$ & population & 605 & $23.12 \pm 0.98$ & $-1.33 \pm 3.40$ \\
\hline Myanmar [34] & female & & & 893 & $22.54 \pm 1.04$ & $-1.16 \pm 3.12$ \\
\hline Denmark [35] & male & 67.9 & population & 325 & $23.74 \pm 1.01$ & $1.05 \pm 2.19$ \\
& female & 68.1 & population & 241 & $23.40 \pm 1.30$ & $0.10 \pm 1.80$ \\
\hline Mongolia [36] & male & $40-49$ & 368 & $23.00 \pm 1.30$ & $-0.30 \pm 1.60$ \\
\hline Jordan [37] & female & & population & 450 & $23.33 \pm 1.02$ & $-0.74 \pm 1.84$ \\
& male & $29.3 \pm 7.45$ & 643 & $22.99 \pm 0.97$ & $-0.95 \pm 1.58$ \\
\hline Singapore [38] & female & $27.4 \pm 6.45$ & population & 457 & $23.54 \pm 1.10$ & $-0.40 \pm 2.41$ \\
& male & $>40$ & & 547 & $22.98 \pm 1.16$ & $-0.56 \pm 2.89$ \\
\hline Australia [39] & female & & family & 723 & $25.53 \pm 1.50$ & $-2.10 \pm 3.12$ \\
\hline
\end{tabular}

Age distribution is preferred to be presented as means \pm standard deviation. If the references did not provide such information, then other forms of age range are shown.

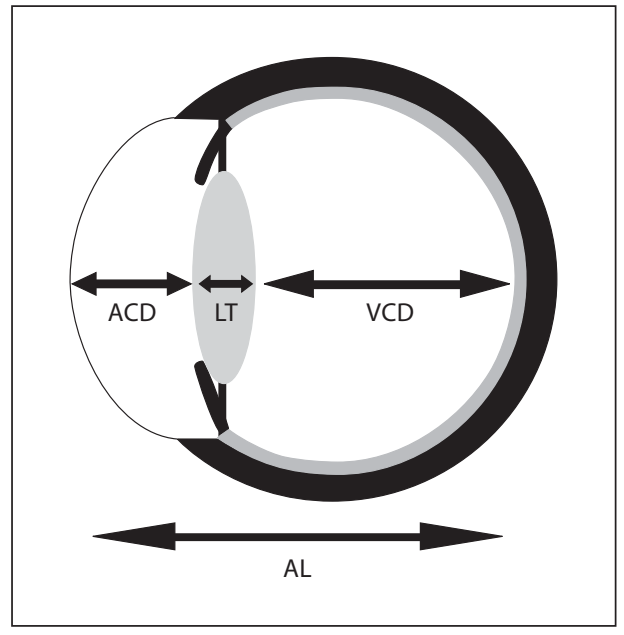

Fig. 1. Illustration of AL. ACD = Anterior chamber depth; $\mathrm{LT}=$ Lens thickness; VCD = vitreous chamber depth.

underlying mechanism. So far, more than 20 chromosomal areas have been proposed to contain potential myopia genes, but further attempts need to narrow down these regions and pinpoint the corresponding genes [60]. Evidence supports strong genetic components in the de- termination of AL. Children with myopic parents have a higher chance of being affected and have longer AL than those without myopic parents [61]. Twin studies also demonstrated that AL is highly heritable and genetic effects can explain up to $88 \%$ of this parameter [62,63]. Segregation analyses suggested that AL is under polygenic control [64]. Moreover, a large proportion of correlation between AL and myopia can be explained by these genetic effects, which indicates that AL and myopia may share common genes [65]. AL reflects the sum of the thickness of the lens, ACD and the length of the vitreous chamber (fig. 1) [66]. Research has shown that part of the heritability of AL is mediated by ACD [67]. In 2004, Biino et al. [33] performed a linkage analysis on extended pedigrees and discovered a locus on 2p24 possibly containing a gene for AL. Afterwards, using twin samples, Zhu et al. [68] reported the evidence for linkage of AL to the long arm of chromosome 5. To our knowledge, these were the only 2 regions reported so far for AL and have not been fine mapped yet.

$\mathrm{AL}$ is an endophenotype of myopia. Both AL and myopia (in refractive error) can be analysed as a quantitative trait using linkage studies. However, AL is much more suitable. The phenotype of myopia, especially high myopia, is commonly accompanied with other eye disorders 
Table 4. Heritability comparisons between AL and myopia

\begin{tabular}{llll}
\hline \multirow{2}{*}{ Trait } & \multicolumn{3}{l}{ Heritability } \\
\cline { 2 - 4 } & twins & sibs & nuclear families \\
\hline AL [65] & 0.88 & 0.73 & 0.75 \\
Myopia [39] & 0.82 & 0.50 & 0.21 \\
\hline
\end{tabular}

Table 5. Comparison between heritability of AL and heritability of refractive error (RE)

\begin{tabular}{llll}
\hline Country or region & Study type & $\begin{array}{l}\text { Heritability } \\
\text { of AL, \% }\end{array}$ & $\begin{array}{l}\text { Heritability } \\
\text { of RE, \% }\end{array}$ \\
\hline $\begin{array}{llll}\text { Sardinia, Italy [33] } \\
\quad \text { Male }\end{array}$ & family & 60 & $18-27$ \\
$\quad$ Female & family & 31 & 33 \\
Taiwan [70] & twin & 67 & $89-91$ \\
USA [67] & twin & 94 & 58 \\
France [64] & population & 67 & 20 \\
\hline
\end{tabular}

Only references containing both AL and RE heritability information are selected.

such as cataract, glaucoma and chorioretinal abnormalities [69], thus would inevitably involve some confounders and may lead to biased conclusions. However, AL, as a clean trait, could be studied in general optical healthy populations and subjects with low myopia to avoid those confounders. Some reported that the heritability of myopia varies significantly among studies with different family structures, while the heritability of AL remains quite consistent (table 4) $[39,65]$. Trait variance of AL caused by environmental factors was only around $6 \%$ contrasting that of myopia from 14 to $33 \%[39,65]$. Thus, using $\mathrm{AL}$ as an endophenotype could avoid or minimise the substantial bias caused by a more complex myopic trait due to instability of heritability. Table 5 summarises the studies that calculated both heritability of AL and heritability of refractive error [33,64, 67, 70]. Most studies showed a higher heritability of AL than refractive error. $\mathrm{AL}$ as a clean and simple endophenotype may bring some advantages to the research field of myopia. This conclusion was partly supported by the first genome-wide association study (GWAS) on myopia performed by a Japanese group [71]. In addition to using general populations as controls, they defined high myopia as $\mathrm{AL}>28 \mathrm{~mm}$ re- gardless of refractive error information. A susceptible locus on 11q24.1 was then discovered by this case-control GWAS approach.

\section{AL and Myopia Animal Models}

It is well confirmed that ocular growth is affected by the quality of visual experience during early life. Failure to induce myopia in dark-reared animals suggests that visual experience is a trigger of eye growth [72]. Animal models of myopia have been successfully established in several species including the monkey, tree shrew, marmoset, chick and the pig [30]. Various methods can be applied to achieve myopia, such as form deprivation, minus lens-induced optical defocus and restricted visual environment conditions [30]. Eyes with induced myopia were observed to have longer AL. For example, negative lenses produce hyperopic defocus and increase the rate of eye growth in monkeys [73]. Conversely, positive lenses lead to myopic defocus and decrease eye growth [74]. It is worth mentioning that such eyes with induced myopia showed evidence of recovery when the inducing factors were removed, and this recovery was inversely related to age $[75,76]$. The monkey eyes showed evidence of strong recovery ability. Even $1 \mathrm{~h} /$ day of unrestricted viewing can reduce around $50 \%$ of the myopia induced by a 17 -week period of deprivation [77]. This suggests the existence of an active emmetropisation mechanism, which controls the location of the retina by remodelling of the sclera so that images can be focused on the focal plane [78]. A molecular signalling cascade seems to be involved in this process. This is probably through the neuro-epithelium and the choroid, and involves a remodelling of the scleral extracellular matrix. In turn, this would cause AL to increase due to lengthening of the vitreous chamber [79, 80]. Scientists are working on strengthening the sclera in order to prevent the elongation of AL. One method is called collagen cross-linking, which will generate a more stable internal structure of the sclera by inducing intraand interfibrillar collagen cross-links [81]. Physical crosslinking by combined riboflavin-ultraviolet or riboflavinblue light and chemical cross-linking by glyceraldehydes, glutaraldehyde and aliphatic $\beta$-nitro alcohols were proven to increase biomechanical strength in both human and animal sclera [81-85]. Compared with other treatments of myopia, cross-linking would correct a cause instead of an effect. However, severe side effects can happen to other ocular structures such as the retina and cornea when cross-linking [81, 82]. Recently, successful cross- 
linking approaches without severe side effects were reported by Wollensak and Iomdina $[86,87]$. Chick models on axial myopia also suggested the involvement of genes controlling body size [88].

\section{Questions Requiring Answers in the Future}

Myopia, as a complex trait, is influenced by both genetic and environmental factors. However, none of the myopia genes have been confirmed so far despite multiple candidate loci being proposed. Currently, 18 regions from MYP1 to MYP18 have been approved by the HUGO Gene Nomenclature Committee. These regions were well described by Tang et al. [60] except the latest one - the MYP18 region. This spans from 14q21.1 to $14 \mathrm{q} 24.2$ and was recently found in a consanguineous Chinese family [89]. This is the first report of an autosomal recessive inheritance model of high myopia.

Candidate genes such as PAX6, MFRP, MYOC, MMP, $U M O D L 1$ and collagen genes have been studied on single or multiple single-nucleotide polymorphism bases [90]. These candidates have good biological evidence to participate in the process of myopia genesis or progression. For example, polymorphisms in the $M M P$ genes may affect the activities of enzymes degrading matrix proteins and modulate sclera extensibility. However, lessons from GWAS studies on other complex traits such as coronary heart disease showed that most of the traditional candidate genes with solid biological connection with the trait could not be replicated in the GWAS [91]. And those discovered loci were not previously suspected as candidates [91]. GWAS is a good approach to detect major genes for myopia and sheds light on the molecular basis of this disorder as well as identifies possible pathways. However, special care needs to be taken when designing GWAS to avoid possible confounders.

It still remains unclear as to what roles the environmental factors play in relation to human myopia. Are they only triggers or decisive factors? It has been suggested that environmental factors such as extensive near work act as triggers of myopia [29]. The expression of $A L$ genes activated by environmental factors leads to the elongation of AL. In environments of extensive near work, such as some high schools in East Asia, where students perform more reading and writing due to higher education pressure, a case-control GWAS study design would be helpful to discover trigger genes for axial myopia or in other words, genes for AL. Sorsby and Leary [92] suggested that ocular growth ceases around the age of 14-15 years based on a cross-section study involving 1,500 individuals aged from 3 to 22 years. On the other hand, myopia progress will not stop until the mid twenties for those hard-working students. In these 10 years, adolescents will experience significant changes due to pubertal development. Then the question is whether anything related to puberty, for example endocrine changes, will also affect the progress of myopia or the elongation of AL. If the extensive near work occurs after the age of 30 years, will it have the same consequence as when it occurs in teenagers? Why does AL generally decrease in the old? Is this process a simple reversal of axial elongation or completely caused by a different mechanism?

Animal models have provided useful and interesting theories concerning myopia and AL but species-specific differences in ocular structures make current extrapolations to human eye development somewhat tenuous. Creative new studies of myopia and its primary determinant, $\mathrm{AL}$, will be able to provide valuable predictive information and effective treatment of this widespread disorder.

\section{References}

1 Casson RJ, Newland HS, Muecke J, McGovern S, Durkin S, Sullivan T, Aung T: Prevalence and causes of visual impairment in rural Myanmar: the Meiktila Eye Study. Ophthalmology 2007;114:2302-2308.

$\checkmark 2$ Rein DB, Zhang P, Wirth KE, Lee PP, Hoerger TJ, McCall N, Klein R, Tielsch JM, Vijan $\mathrm{S}$, Saaddine J: The economic burden of major adult visual disorders in the United States. Arch Ophthalmol 2006;124:1754-1760. $\checkmark 3$ Kempen JH, Mitchell P, Lee KE, Tielsch JM, Broman AT, Taylor HR, Ikram MK, Congdon NG, O’Colmain BJ, Eye Diseases Prevalence Research Group: The prevalence of refractive errors among adults in the United States, Western Europe, and Australia. Arch Ophthalmol 2004;122:495-505.

-4 Sawada A, Tomidokoro A, Araie M, Iwase A, Yamamoto T, Tajimi Study Group: Refractive errors in an elderly Japanese population: the Tajimi study. Ophthalmology 2008;115: 363-370.
5 Yekta AA, Fotouhi A, Khabazkhoob M, Hashemi H, Ostadimoghaddam H, Heravian J, Mehravaran S: The prevalence of refractive errors and its determinants in the elderly population of Mashhad, Iran. Ophthalmic Epidemiol 2009;16:198-203.

6 6 Bourne RR, Dineen BP, Ali SM, Noorul Huq DM, Johnson GJ: Prevalence of refractive error in Bangladeshi adults: results of the National Blindness and Low Vision Survey of Bangladesh. Ophthalmology 2004;111: 1150-1160. 
7 Liang YB, Wong TY, Sun LP, Tao QS, Wang JJ, Yang XH, Xiong Y, Wang NL, Friedman DS: Refractive errors in a rural Chinese adult population: the Handan eye study. Ophthalmology 2009;116:2119-2127.

> He M, Huang W, Li Y, Zheng Y, Yin Q, Foster PJ: Refractive error and biometry in older Chinese adults: the Liwan eye study. Invest Ophthalmol Vis Sci 2009;50:5130-5136.

9 Krishnaiah S, Srinivas M, Khanna RC, Rao GN: Prevalence and risk factors for refractive errors in the South Indian adult population: the Andhra Pradesh Eye disease study. Clin Ophthalmol 2009;3:17-27.

-10 Wong TY, Foster PJ, Hee J, Ng TP, Tielsch JM, Chew SJ, Johnson GJ, Seah SK: Prevalence and risk factors for refractive errors in adult Chinese in Singapore. Invest Ophthalmol Vis Sci 2000;41:2486-2494.

-11 Midelfart A, Kinge B, Midelfart S, Lydersen $S$ : Prevalence of refractive errors in young and middle-aged adults in Norway. Acta Ophthalmol Scand 2002;80:501-505.

-12 Anton A, Andrada MT, Mayo A, Portela J, Merayo J: Epidemiology of refractive errors in an adult European population: the Segovia study. Ophthalmic Epidemiol 2009;16: 231-237.

13 Dirani M, Chan YH, Gazzard G, Hornbeak DM, Leo SW, Selvaraj P, Zhou B, Young TL, Mitchell P, Varma R, Wong TY, Saw SM: Prevalence of refractive error in Singaporean Chinese children: the Strabismus, Amblyopia, and Refractive Error in Young Singaporean Children (STARS) Study. Invest Ophthalmol Vis Sci 2010;51:1348-1355.

- 14 Giordano L, Friedman DS, Repka MX, Katz J, Ibironke J, Hawes P, Tielsch JM: Prevalence of refractive error among preschool children in an urban population: the Baltimore Pediatric Eye Disease Study. Ophthalmology 2009; 116:739-746.

15 Multi-Ethnic Pediatric Eye Disease Study Group: Prevalence of myopia and hyperopia in 6- to 72-month-old African American and Hispanic children: the Multi-Ethnic Pediatric Eye Disease Study. Ophthalmology 2010; 117:140-147.

- 16 Ip JM, Rose KA, Morgan IG, Burlutsky G, Mitchell P: Myopia and the urban environment: findings in a sample of 12-year-old Australian school children. Invest Ophthalmol Vis Sci 2008;49:3858-3863.

17 Congdon N, Wang Y, Song Y, Choi K, Zhang M, Zhou Z, Xie Z, Li L, Liu X, Sharma A, Wu B, Lam DS: Visual disability, visual function, and myopia among rural Chinese secondary school children: the Xichang Pediatric Refractive Error Study (X-PRES) - report 1. Invest Ophthalmol Vis Sci 2008;49:2888-2894.

-18 Jamali P, Fotouhi A, Hashemi H, Younesian M, Jafari A: Refractive errors and amblyopia in children entering school: Shahrood, Iran. Optom Vis Sci 2009;86:364-369.

-19 Barnes M, Williams C, Lumb R, Harrad RA, Sparrow JM, Harvey I, ALSPAC study team: The prevalence of refractive errors in a UK birth cohort of children aged 7 years. Invest Ophthalmol Vis Sci 2001;42:S389.
20 Saw SM, Carkeet A, Chia KS, Stone RA, Tan DT: Component dependent risk factors for ocular parameters in Singapore Chinese children. Ophthalmology 2002;109:20652071.

21 Czepita D, Mojsa A, Zejmo M: Prevalence of myopia and hyperopia among urban and rural schoolchildren in Poland. Ann Acad Med Stetin 2008;54:17-21.

22 Uzma N, Kumar BS, Khaja Mohinuddin Salar BM, Zafar MA, Reddy VD: A comparative clinical survey of the prevalence of refractive errors and eye diseases in urban and rural school children. Can J Ophthalmol 2009;44:328-333.

23 Gronlund MA, Andersson S, Aring E, Hard AL, Hellstrom A: Ophthalmological findings in a sample of Swedish children aged 4-15 years. Acta Ophthalmol Scand 2006;84: 169-176.

24 Hashim SE, Tan HK, Wan-Hazabbah WH, Ibrahim M: Prevalence of refractive error in malay primary school children in a suburban area of Kota Bharu, Kelantan, Malaysia. Ann Acad Med Singapore 2008;37:940-946.

25 Lam CS, Goldschmidt E, Edwards MH Prevalence of myopia in local and international schools in Hong Kong. Optom Vis Sci 2004;8:317-322.

26 Woo WW, Lim KA, Yang H, Lim XY, Liew F, Lee YS, Saw SM: Refractive errors in medical students in Singapore. Singapore Med J 2004; 45:470-474.

27 Resnikoff S, Pascolini D, Etya'ale D, Kocur I, Pararajasegaram R, Pokharel GP, Mariotti SP: Global data on visual impairment in the year 2002. Bull World Health Organ 2004; 82:844-851.

28 Dandona L, Dandona R: What is the global burden of visual impairment? BMC Med 2006;4:6.

29 Zejmo M, Forminska-Kapuscik M, Pieczara E, Filipek E, Mrukwa-Kominek E, Samochowiec-Donocik E, Leszczynski R, Smuzyńska M: Etiopathogenesis and management of high-degree myopia. Part I. Med Sci Monit 2009; 15:199-202.

30 Young TL, Metlapally R, Shay AE: Complex trait genetics of refractive error. Arch Ophthalmol 2007;125:38-48.

31 Tron EJ: The optical elements of the refractive power of the eye; in Ridley F, Sorsby A (eds): Modern Trends in Ophthalmology. New York, Hoeber Press, 1940, p 245.

32 Fotedar R, Wang JJ, Burlutsky G, Morgan IG, Rose K, Wong TY, Mitchell P: Distribution of axial length and ocular biometry measured using partial coherence laser interferometry (IOL Master) in an older white population. Ophthalmology 2010;117:417-423.

33 Biino G, Palmas MA, Corona C, Prodi D, Fanciulli M, Sulis R, Serra A, Fossarello M, Pirastu M: Ocular refraction: heritability and genome-wide search for eye morphometry traits in an isolated Sardinian population. Hum Genet 2005;116:152-159.
34 Warrier S, Wu HM, Newland HS, Muecke J, Selva D, Aung T, Casson RJ: Ocular biometry and determinants of refractive error in rural Myanmar: the Meiktila Eye Study. Br J Ophthalmol 2008;92:1591-1594.

35 Olsen T, Arnarsson A, Sasaki H, Sasaki K, Jonasson F: On the ocular refractive components: the Reykjavik Eye Study. Acta Ophthalmol Scand 2007;85:361-366.

36 Wickremasinghe S, Foster PJ, Uranchimeg D, Lee PS, Devereux JG, Alsbirk PH, Machin D, Johnson GJ, Baasanhu J: Ocular biometry and refraction in Mongolian adults. Invest Ophthalmol Vis Sci 2004;45:776-783.

37 Mallen EA, Gammoh Y, Al-Bdour M, Sayegh FN: Refractive error and ocular biometry in Jordanian adults. Ophthalmic Physiol Opt 2005;25:302-309.

$>38$ Wong TY, Foster PJ, Ng TP, Tielsch JM, Johnson GJ, Seah SK: Variations in ocular biometry in an adult Chinese population in Singapore: the Tanjong Pagar Survey. Invest Ophthalmol Vis Sci 2001;42:73-80.

39 Chen CY, Scurrah KJ, Stankovich J, Garoufalis P, Dirani M, Pertile KK, Richardson AJ, Mitchell P, Baird PN: Heritability and shared environment estimates for myopia and associated ocular biometric traits: the Genes in Myopia (GEM) family study. Hum Genet 2007;121:511-520.

40 Young TL, Metlapally R, Shay AE: Complex trait genetics of refractive error. Arch Ophthalmol 2007;125:38-48.

41 Mallen EA, Gammoh Y, Al-Bdour M, Sayegh FN: Refractive error and ocular biometry in Jordanian adults. Ophthalmic Physiol Opt 2005;25:302-309.

42 Chen MJ, Liu YT, Tsai CC, Chen YC, Chou CK, Lee SM: Relationship between central corneal thickness, refractive error, corneal curvature, anterior chamber depth and axial length. J Chin Med Assoc 2009;72:133-137.

43 Hung GK, Ciuffreda KJ: Model of human refractive error development. Curr Eye Res 1999;19:41-52.

44 Shufelt C, Fraser-Bell S, Ying-Lai M, Torres M, Varma R, Los Angeles Latino Eye Study Group - refractive error, ocular biometry, and lens opalescence in an adult population: the Los Angeles Latino Eye Study. Invest Ophthalmol Vis Sci 2005;46:4450-4460.

45 Lee KE, Klein BE, Klein R, Quandt Z, Wong TY: Association of age, stature, and education with ocular dimensions in an older white population. Arch Ophthalmol 2009; 127:88-93.

46 Mutti DO, Hayes JR, Mitchell GL, Jones LA, Moeschberger ML, Cotter SA, Kleinstein RN, Manny RE, Twelker JD, Zadnik K, CLEERE Study Group: Refractive error, axial length, and relative peripheral refractive error before and after the onset of myopia. Invest Ophthalmol Vis Sci 2007;48:2510-2519.

$\checkmark 47$ Gordon RA, Donzis PB: Refractive development of the human eye. Arch Ophthalmol 1985;103:785-789.

48 Brown NP, Koretz JF, Bron AJ: The development and maintenance of emmetropia. Eye 1999;13:83-92. 
49 Lambert SR: The effect of age on the retardation of axial elongation following a lensectomy in infant monkeys. Arch Ophthalmol 1998;116:781-784.

-50 Kugelberg U, Zetterstrom C, Syren-Nordqvist S: Ocular axial length in children with unilateral congenital cataract. Acta Ophthalmol Scand 1996;74:220-223.

-51 Flitcroft DI, Knight-Nanan D, Bowell R, Lanigan B, O'Keefe M: Intraocular lenses in children: changes in axial length, corneal curvature, and refraction. Br J Ophthalmol 1999;83:265-269.

- 52 Leiba H, Springer A, Pollack A: Ocular axial length changes in pseudophakic children after traumatic and congenital cataract surgery. J AAPOS 2006;10:460-463.

-53 Mutti DO, Mitchell GL, Jones LA, Friedman NE, Frane SL, Lin WK, Moeschberger ML, Zadnik K: Axial growth and changes in lenticular and corneal power during emmetropization in infants. Invest Ophthalmol Vis Sci 2005;46:3074-3080.

- 54 Jivrajka R, Shammas MC, Boenzi T, Swearingen M, Shammas HJ: Variability of axial length, anterior chamber depth, and lens thickness in the cataractous eye. J Cataract Refract Surg 2008;34:289-294.

- 55 Osuobeni EP: Ocular components values and their intercorrelations in Saudi Arabians. Ophthalmic Physiol Opt 1999;19:489497.

56 Su DH, Wong TY, Foster PJ, Tay WT, Saw SM, Aung T: Central corneal thickness and its associations with ocular and systemic factors: the Singapore Malay Eye Study. Am J Ophthalmol 2009;147:709-716.

-57 Stone RA, Quinn GE, Francis EL, Ying GS, Flitcroft DI, Parekh P, Brown J, Orlow J, Schmid G: Diurnal axial length fluctuations in human eyes. Invest Ophthalmol Vis Sci 2004;45:63-70.

58 Wilson LB, Quinn GE, Ying GS, Francis EL, Schmid G, Lam A, Orlow J, Stone RA: The relation of axial length and intraocular pressure fluctuations in human eyes. Invest Ophthalmol Vis Sci 2006;47:1778-1784.

-59 Read SA, Collins MJ, Iskander DR: Diurnal variation of axial length, intraocular pressure, and anterior eye biometrics. Invest Ophthalmol Vis Sci 2008;49:2911-2918.

-60 Tang WC, Yap MK, Yip SP: A review of current approaches to identifying human genes involved in myopia. Clin Exp Optom 2008; 91:4-22.

-61 Kurtz D, Hyman L, Gwiazda JE, Manny R, Dong LM, Wang Y, Scheiman M, COMET Group: Role of parental myopia in the progression of myopia and its interaction with treatment in COMET children. Invest Ophthalmol Vis Sci 2007;48:562-570.

-62 He M, Hur YM, Zhang J, Ding X, Huang W, Wang D: Shared genetic determinant of axial length, anterior chamber depth, and angle opening distance: the Guangzhou Twin Eye Study. Invest Ophthalmol Vis Sci 2008;49: 4790-4794.
63 Lopes MC, Andrew T, Carbonaro F, Spector TD, Hammond CJ: Estimating heritability and shared environmental effects for refractive error in twin and family studies. Invest Ophthalmol Vis Sci 2009;50:126-131.

64 Paget S, Vitezica ZG, Malecaze F, Calvas P: Heritability of refractive value and ocular biometrics. Exp Eye Res 2008;86:290-295.

65 Dirani M, Shekar SN, Baird PN: Evidence of shared genes in refraction and axial length: the Genes in Myopia (GEM) twin study. Invest Ophthalmol Vis Sci 2008;49:4336-4339.

66 Phillips JR: Monovision slows juvenile myopia progression unilaterally. Br J Ophthalmol 2005;89:1196-1200.

67 Klein AP, Suktitipat B, Duggal P, Lee KE, Klein R, Bailey-Wilson JE, Klein BE: Heritability analysis of spherical equivalent, axial length, corneal curvature, and anterior chamber depth in the Beaver Dam Eye Study. Arch Ophthalmol 2009;127:649-655.

68 Zhu G, Hewitt AW, Ruddle JB, Kearns LS Brown SA, Mackinnon JR, Chen CY, Hammond CJ, Craig JE, Montgomery GW, Martin NG, Mackey DA: Genetic dissection of myopia: evidence for linkage of ocular axial length to chromosome 5q. Ophthalmology 2008;115:1053-1057.

69 Saw SM, Gazzard G, Shih-Yen EC, Chua WH: Myopia and associated pathological complications. Ophthalmic Physiol Opt 2005;25:381-391.

70 Tsai MY, Lin LL, Lee V, Chen CJ, Shih YF: Estimation of heritability in myopic twin studies. Jpn J Ophthalmol 2009;53:615-622.

71 Nakanishi H, Yamada R, Gotoh N, Hayashi H, Yamashiro K, Shimada N, Ohno-Matsui K, Mochizuki M, Saito M, Iida T, Matsuo K, Tajima K, Yoshimura N, Matsuda F. A genome-wide association analysis identified a novel susceptible locus for pathological myopia at 11q24.1. PLoS Genet 2009; 5:e1000660.

72 Raviola E, Wiesel TN: An animal model of myopia. N Engl J Med 1998;312:1609-1615.

73 Hung LF, Crawford ML, Smith EL: Spectacle lenses alter eye growth and the refractive status of young monkeys. Nat Med 1995;1:761765.

74 Norton TT, Siegwart JT Jr: Animal models of emmetropization: matching axial length to the focal plane. J Am Optom Assoc 1995;66: 405-414.

75 Zhou X, Lu F, Xie R, Jiang L, Wen J, Li Y, Shi J, He T, Qu J: Recovery from axial myopia induced by a monocularly deprived facemask in adolescent (7-week-old) guinea pigs Vision Res 2007;47:1103-1111.

76 Siegwart JT Jr, Norton TT: The susceptible period for deprivation-induced myopia in tree shrew. Vision Res 1998;38:3505-3515.
77 Smith EL 3rd, Hung LF, Kee CS, Qiao Y: Effects of brief periods of unrestricted vision on the development of form-deprivation myopia in monkeys. Invest Ophthalmol Vis Sci 2002;43:291-299.

78 Rada JA, Shelton S, Norton TT: The sclera and myopia. Exp Eye Res 2006;82:185-200.

79 Siegwart JT Jr, Norton TT: Regulation of the mechanical properties of tree shrew sclera by the visual environment. Vision Res 1999;39: 387-407.

80 McBrien NA, Jobling AI, Gentle A: Biomechanics of the sclera in myopia: extracellular and cellular factors. Optom Vis Sci 2009;86: 23-30.

81 Wollensak G, Iomdina E, Dittert DD, Salamatina O, Stoltenburg G: Cross-linking of scleral collagen in the rabbit using riboflavin and UVA. Acta Ophthalmol Scand 2005;83: 477-482.

82 Wollensak G, Spoerl E: Collagen crosslinking of human and porcine sclera. J Cataract Refract Surg 2004;30:689-695.

83 Paik DC, Wen Q, Braunstein RE, Airiani S, Trokel SL: Initial studies using aliphatic beta-nitro alcohols for therapeutic corneal cross-linking. Invest Ophthalmol Vis Sci 2009;50:1098-1105.

84 Danilov NA, Ignatieva NY, Iomdina EN, Semenova SA, Rudenskaya GN, Grokhovskaya TE, Lunin VV: Stabilization of scleral collagen by glycerol aldehyde cross-linking. Biochim Biophys Acta 2008;1780:764-772.

85 Iseli HP, Spoerl E, Wiedemann P, Krueger RR, Seiler T: Efficacy and safety of blue-light scleral cross-linking. J Refract Surg 2008; 24:S752-S755.

86 Wollensak G, Iomdina E: Long-term biomechanical properties of rabbit sclera after collagen crosslinking using riboflavin and ultraviolet A (UVA). Acta Ophthalmol 2009; 87:193-198.

87 Wollensak G, Iomdina E: Long-term biomechanical properties after collagen crosslinking of sclera using glyceraldehyde. Acta Ophthalmol 2008;86:887-893.

- 88 Prashar A, Hocking PM, Erichsen JT, Fan Q, Saw SM, Guggenheim JA: Common determinants of body size and eye size in chickens from an advanced intercross line. Exp Eye Res 2009;89:42-48.

89 Yang Z, Xiao X, Li S, Zhang Q: Clinical and linkage study on a consanguineous Chinese family with autosomal recessive high myopia. Mol Vis 2009;15:312-318.

90 Hornbeak DM, Young TL: Myopia genetics: a review of current research and emerging trends. Curr Opin Ophthalmol 2009;20: 356-362.

91 Wang Q: Molecular genetics of coronary artery disease. Curr Opin Cardiol 2005;20: 182-188.

$\$ 92$ Sorsby A, Leary GA: A longitudinal study of refraction and its components during growth. Spec Rep Ser Med Res Counc (GB) 1969;309:1-41. 